JURNAL KOMUNITAS

\title{
PENGEMBANGAN BUDAYA SEKOLAH BERPRESTASI: STUDI TENTANG PENANAMAN NILAI DAN ETOS BERPRESTASI DI SMA KARANGTURI
}

\author{
Agus Yuliono $\bowtie$ \\ Program Pascasarjana Antropologi Budaya, Universitas Gajah Mada, Yogyakarta, Indonesia
}

\section{Info Artikel \\ Sejarah Artikel: \\ Diterima Juni 2011 \\ Disetujui Juli 2011 \\ Dipublikasikan September 2011}

\section{Keywords:}

achievement;

investement of values and

ethos;

school culture.

\begin{abstract}
Abstrak
Tujuan penelitian ini adalah untuk mendeskripsikan bentuk budaya sekolah berprestasi, proses penanaman nilai dan etos berprestasi kepada peserta didik dan mengetahui implikasi dari pengembangan budaya sekolah berprestasi di SMA Karangturi. Penelitian ini menggunakan pendekatan deskriptif kualitatif. Pengumpulan data menggunakan teknik observasi, wawancara dan dokumentasi. Hasil penelitian menunjukkan bahwa bentuk budaya sekolah berprestasi di SMA Karangturi mencakup empat poin yaitu: keseimbangan antara pembinaan akademik dan nonakademik, penanaman karakter melalui pelajaran, budaya mencintai almamater dan pentingnya nilai kerokhanian. Penanaman nilai dan etos berprestasi pada peserta didik dilakukan melalui kegiatan orientasi sekolah, proses pembelajaran, evaluasi belajar, ekstrakurikuler, penghargaan prestasi, kecintaan terhadap almamater, keteladanan guru, kerjasama dengan orangtua peserta didik dan seragam patriot sebagai media penanaman budaya berprestasi. Implikasi penanaman pengembangan budaya sekolah berprestasi di SMA Karangturi terdapat dalam input (penerimaan siswa baru dan pencarian siswa berpotensi), proses (pengembangan program sekolah serta pengembangan kerjasama) dan output (prestasi akademik dan nonakademik serta jumlah alumni yang melanjutkan ke perguruan tinggi).
\end{abstract}

\begin{abstract}
The objective of this study is to describe a model of school achievement culture, the cultivation of values and ethos of achievement to students and know the implications of the development of school culture on students' achievement in Karangturi high school. This study used a qualitative descriptive approach. Techniques of collecting data were observation, interviews and documentation. This study uses sources and methods triangulation for data validation. The results show that the school achievement culture in Karangturi high school contains four pillars, namely: a balance between academic and non-academic achievement, building character through the lesson, love the school and the importance of religious values. The building of values and ethos of achievement on student is done through school orientation activities, learning process, evaluation, extracurricular achievement awards, love the school, teachers exemplary, cooperation with parents and students, patriot uniform as media to build achievement culture. The implications of the building of achievement culture manifest in the input (new admissions and the search for potential students), processes (development of school programs and development of cooperation) and output (academic and non-academic achievement and the number of alumni who go on to college).
\end{abstract}

(C) 2011 Universitas Negeri Semarang 


\section{PENDAHULUAN}

Pendidikan di sekolah pada hakikatnya merupakan usaha untuk mentransmisikan nilai kebudayaan, yang bertujuan mempertahankan, mengembangkan, dan mentransformasikan kebudayaan yang dimiliki masyarakat. Pengembangan nilai, kelakuan, rencana dan strategi sekolah secara terpola menghasilkan suatu budaya sekolah yang dianut bersama oleh pelaku-pelaku di dalamnya.

Pengertian budaya menurut Koentjaraningrat (2000:180) adalah keseluruhan sistem gagasan, tindakan dan hasil karya manusia dalam rangka kehidupan masyarakat yang dijadikan milik diri manusia dengan belajar. Pemakaian istilah antara "budaya" dengan "kebudayaan" selama ini dianggap memiliki kesamaan arti. Padahal kedua istilah tersebut memiliki perbedaan. Masinambow (1997:6) menyatakan bahwa budaya lebih mengacu kepada pengertian tingkah laku atau pola perilaku, kebiasaan, atau nilai dalam sistem nilai. Budaya diartikan sebagai suatu cara hidup tertentu yang terlihat dalam masyarakat. Sedangkan kebudayaan lebih mengacu kepada keseluruhannya (termasuk yang diacu budaya), yaitu kepada semua aspek seperti kesenian, organisasi sosial, mata pencaharian, bahasa, dan religi yang terintegrasi menurut suatu pola keterikatan tertentu sehingga memberikan corak khas kepada masyarakat yang bersangkutan (Masinambow, 1997:6).

Budaya sekolah merupakan ciri khas, karakter atau watak, dan citra sekolah tersebut di masyarakat luas. Penerapan kultur sekolah yang tepat akan mempunyai pengaruh yang berarti dalam aktivitas belajar siswa, maupun dalam mempengaruhi guru untuk melakukan pekerjaan yang lebih efisien dan efektif untuk mencapai kinerja guru yang baik (Bukhori dan Anita, 2009). Budaya sekolah akan mempengaruhi suasana kelas, baik kebebasan yang dinikmati peserta didik dalam mengembangkan pikiran dan prestasinya ataupun sebaliknya bisa menjadi pengekangan dan keterbatasan tehadap pengembangan peserta didik dan sekolah itu sendiri. Penanaman nilai-nilai budaya sekolah dilaksanakan terutama saat pembelajaran di kelas dan akan berlanjut dalam pola kelakuan dan interaksi di luar kelas. Peserta didik pada saat pertama memasuki lingkungan sekolah akan mengalami proses sosialisasi dimana peserta didik memahami dan menjalankan budaya sekolah. Proses pembelajaran peserta didik dapat berjalan lancar karena ada budaya sekolah yang menentukan kelakuan dan tujuan yang diharapkan oleh guru, peserta didik dan para stakeholder. Nilai-nilai dan norma yang berlangsung di dalam sekolah juga harus memperhatikan budaya masyarakat terutama yang berlaku dalam keluarga peserta didik.

Budaya berprestasi merupakan bentuk budaya sekolah yang menjadi poin utama di setiap sekolah. Menurut Mc. Clleland dalam Djiwandono, motivasi yang paling penting untuk pendidikan adalah motivasi berprestasi, dimana seseorang cenderung berjuang untuk mencapai sukses atau memilih suatu kegiatan yang berorientasi untuk tujuan sukses atau gagal (Garliah dan Nasution, 2005). Fernald \& Fernald (1999) mengungkapkan bahwa ada beberapa hal yang mempengaruhi motivasi berprestasi, yakni keluarga dan kebudayaan; konsep diri; jenis kelamin dan pengakuan prestasi (Garliah dan Nasution, 2005).

SMA Karangturi merupakan sekolah berprestasi yang memiliki suatu karakter budaya sekolah yang berbeda dengan sekolah lainnya. Banyak prestasi yang telah diraih SMA Karangturi dalam bidang akademik maupun non akademik di tingkat lokal, nasional, bahkan internasional. Dalam bidang akademik, SMA Karangturi merupakan salah satu yang terbaik dari sekolah-sekolah unggulan di Semarang. Salah satu buktinya adalah SMA ini merupakan 1 dari 6 sekolah yang mencapai kelulusan $100 \%$ pada UN 2010. Prestasi akademik juga ditunjukkan dengan beberapa kali menjadi pemenang dalam olimpiade-olimpiade nasional maupun internasional. Hal lain yang menarik dari sekolah ini adalah bahwa kebanyakan lulusannya melanjutkan belajar ke perguruan tinggi di luar negeri.

Dalam bidang non-akademik, SMA Karangturi terkenal berprestasi dalam bidang olahraga, yakni basket, renang dan wushu. 
Agus Yuliono / Komunitas 3 (2) (2011) : 169-179

Tabel 1. Data Prestasi SMA Karangturi Tahun Pelajaran 2010/2011

\begin{tabular}{|c|c|c|}
\hline Lomba & Tingkat & Prestasi \\
\hline World Choir Game & Internasional & Champion \\
\hline $\begin{array}{l}\text { The } 8 \text { th Beijing International Whushu } \\
\text { Invitation Tournament }\end{array}$ & Internasional & Juara 1 \\
\hline FPS ITB ke 22 (Paduan Suara) & Nasional & Juara 1 \\
\hline Akuntansi & Nasional & Juara 2 \\
\hline Lomba Paduan Suara & Nasional & Juara 3 \\
\hline Renang 200 m Ganti & Jateng-DIY & Juara 1 \\
\hline Renang 50 m Kupu & Jaten-DIY & Juara 2 \\
\hline Renang 100 m Kupu & Jateng-DIY & Juara 3 \\
\hline Renang $200 \mathrm{~m}$ Bebas & Jateng-DIY & Juara 3 \\
\hline Matematika-Fisika & Jawa-Bali & Juara 3 \\
\hline Gubernur Cup (Basket Putra) & Propinsi & Juara 1 \\
\hline Gubernur Cup (cheerleader) & Propinsi & Juara 1 \\
\hline IPH Cup 2011 & Propinsi & Juara 1 \\
\hline Gubernur Cup (Basket Putri) & Propinsi & Juara 2 \\
\hline Australian Debate Championship (ADC) & Propinsi & Juara 2 \\
\hline Akuntansi & Propinsi & Juara 2 \\
\hline Cerdas Cermat & Propinsi & Juara 2 \\
\hline Karikatur Pajak & Propinsi & Juara 3 \\
\hline Artikel Perpajakan & Propinsi & Juara 3 \\
\hline Bio Competition & Propinsi & Harapan 1 \\
\hline Lomba Matematika & Propinsi & Harapan 1 \\
\hline Speaking Competition & Kota & Juara 1 \\
\hline Board Games Competition & Kota & Juara 1 \\
\hline Wali Kota Cup (Basket Putra) & Kota & Juara 1 \\
\hline Asov Cup (Basket Putra) & Kota & Juara 1 \\
\hline Wali Kota Cup (Basket Putri) & Kota & Juara 2 \\
\hline Asov Cup (Basket Putri) & Kota & Juara 2 \\
\hline Vocal Group & Kota & Juara 2 \\
\hline Band antar SMA & Kota & Juara 3 \\
\hline Modern Dance & Kota & Juara 3 \\
\hline Board Games Competition & Kota & Juara 3 \\
\hline Lomba Ekonomi & Kota & Juara 3 \\
\hline Tari Pembauran & Kota & Harapan 1 \\
\hline
\end{tabular}

Sumber: Dokumentasi SMA Karangturi.

Sekolah ini berkali-kali memenangkan kompetisi basket antar sekolah se-Indonesia, menjuarai kejuaraan lokal dan regional seperti Walikota Cup dan Gubernur Cup. Beberapa siswa SMA Karangturi bahkan terpilih sebagai pemain basket timnas Indonesia. Dalam olahraga renang, prestasi sekolah ini juga sangat membanggakan. Selain dalam bidang olahraga, bidang seni juga menjadi poin prestasi SMA Karangturi, yakni dalam paduan suara dan musik. Tahun 2011, SMA ini mendapat medali emas dalam kejuaraan paduan suara internasional yang diselenggarakan di Ohio Amerika Serikat. Salah satu siswa SMA Karangturi, seorang pianis dapat menembus persaingan dalam ajang pencarian bakat di stasiun TV nasional "Indonesia's Got Talent".

SMA Karangturi juga memiliki latar belakang budaya yang unik, dimana mayo- 
ritas siswanya adalah keturunan Tionghoa. Di lingkungan masyarakat, SMA Karangturi juga dikenal sebagai sekolah "borjuis". Latar belakang keluarga mempengaruhi banyak hal dalam motivasi berprestasi dan gaya belajar peserta didik. Cara belajar peserta didik yang beraneka ragam tersebut dikenal sebagai gaya belajar (learning style) yang dipengaruhi oleh pengalaman, jenis kelamin, etnis (Philbin, et.al. dalam Prastiti dan Pujiningsih, 2009) dan secara khusus melekat pada setiap individu. Bagaimana budaya sekolah SMA Karangturi berpengaruh terhadap motivasi berprestasi dan kemampuan berprestasi bagi para peserta didik serta bagaimana SMA Karangturi mengelola berbagai aspek yang mendorong motivasi berprestasi menjadi topik kajian budaya sekolah yang sangat menarik.

Di negara maju, riset tentang budaya dan iklim di sekolah telah berkembang baik dan memberikan sumbangan yang cukup signifikan bagi pembentukan sekolahsekolah yang efektif. Olim dkk (2007:254) menyatakan bahwa penelitian budaya dalam mengkaji masalah pendidikan masih kurang karena masalah pendidikan dipandang menjadi area psikologi pendidikan, dengan fokus pada lingkungan kelas seperti didaktik dan metodik.

Berdasarkan latar belakang diatas, sangat penting untuk dilakukan penelitian untuk mengkaji tentang pengembangan budaya sekolah. Peneliti mengambil judul "Pengembangan Budaya Sekolah Berprestasi (Studi Penanaman Nilai dan Etos Berprestasi pada Peserta Didik SMA Karangturi Semarang)". Penelitian ini bertujuan untuk mendeskripsikan bentuk budaya sekolah, proses penanaman nilai dan etos berprestasi kepada peserta didik dan mengetahui implikasi dari pengembangan budaya sekolah berprestasi di SMA Karangturi. Karena membahas tentang budaya sekolah, maka peneliti mengemukakan kajian pustaka tentang definisi budaya sekolah, prinsip-prinsip budaya sekolah dan konsep prestasi. Sedangkan teori yang digunakan untuk membedah permasalahan penelitian adalah Teori Fungsionalisme Struktural serta Teori Sosialisasi (Peter L Berger dan Thomas Luckman).

\section{METODE PENELITIAN}

Penelitian ini merupakan penelitian deskriptif kualitatif yang bertujuan untuk mengemukakan gejala-gejala secara lengkap serta hubungannya satu sama lain di dalam aspek-aspek yang diselidiki. Lokasi dalam penelitian ini adalah SMA Karangturi di Jalan Raden Patah no. 182 - 192 kota Semarang. Fokus penelitian dirinci dalam tiga masalah yaitu: budaya sekolah yang dimiliki SMA Karangturi, proses penanaman nilai dan etos berprestasi kepada peserta didik SMA Karangturi, dan implikasi pengembangan budaya sekolah berprestasi di SMA Karangturi.

Penelitian ini menggunakan sumber data berupa data primer dan data sekunder. Data primer diperoleh dari subyek penelitian yakni guru dan peserta didik di SMA Karangturi Semarang. Intensitas yang rutin antara guru dan peserta dan kontak langsung dalam pembelajaran di dalam kelas maupun diluar kelas dapat menjelaskan tentang budaya sekolah berprestasi di SMA Karangturi. Data primer yakni guru dan peserta didik tersebut diambil sampel (tidak seluruh guru dan peserta didik) dengan pertimbangan tertentu. Disamping itu ada juga informan pendukung yaitu pimpinan sekolah dan alumni SMA Karangturi. Data sekunder didapatkan dari literatur-literatur relevan yang mendukung data penelitian yang diantaranya adalah data sekolah, tata tertib sekolah, rekap data prestasi peserta didik dari tahun 20072011, data ekstrakurikuler Majalah Karturian, Majalah K Magz (Karangturi Magazine).

Pengumpulan data dilakukan dengan teknik observasi, wawancara dan dokumentasi. Pelaksanaan observasi di lingkungan SMA Karangturi dilakukan dengan prosedur ketat yang berlaku di sekolah tersebut. Observasi dilakukan tanpa mengganggu kegiatan pembelajaran. Observasi ditekankan pada fokus-fokus yang berkatan dengan rumusan masalah, yakni meliputi: lingkungan dan prasarana fisik sekolah, simbol-simbol yang berisi pesan-pesan positif berupa tulisan, gambar atau monumen yang ada di lingkungan sekolah serta interaksi dan perilaku warga sekolah terutama para significant other 
dan peserta didik.

\section{HASIL DAN PEMBAHASAN}

Sejarah SMA Karangturi berawal dari seorang bernama The Sien Tjo yang mendirikan sekolah ini pada tanggal 1 Juli 1929. SMA Karangturi memiliki luas 10.000 m2 dengan bangunan tiga lantai, serta memiliki fasilitas sarana dan prasarana yang sangat lengkap dan nyaman. Jumlah total peserta didik yang ada di SMA Karangturi pada tahun ajaran 2011/2012 adalah 737; yang terdiri dari kelas IPA dan IPS. Sebagian besar peserta didik SMA Karangturi adalah etnis Tionghoa. Jumlah Guru SMA Karangturi ada 43 orang. Pendidikan terakhir S2 sebanyak 8 guru, S1 sebanyak 41 guru, D3 sebanyak 2 guru, D1 sebanyak 1 guru dan SMA sebanyak 1 guru.

Norma budaya sekolah di SMA Karangturi dalam teori fungsionalisme struktural disebut fungsi pencapaian tujuan. Pencapaian tujuan juga memerlukan skema alat tujuan yang berupa kulminasi tindakan yang secara intrinsik memuaskan (Johnson, 1990: 130). Skema untuk merealisasikan tujuan SMA Karangturi terwujud dalam norma budaya sekolah. Norma budaya sekolah Karangturi sangat berpengaruh terhadap hubungan sosial di antara Kepala sekolah, guru, peserta didik, Yayasan Pendididikan Nasional (YPN) Karangturi beserta alumni dalam kerjasama, komunikasi, dan keterbukaan dalam pengembangan kualitas sekolah terutama peningkatan prestasi.

Norma budaya sekolah di SMA Karangturi secara umum berwujud pada slogan, visi misi, falsafah pembelajaran dan Patriot sebagai nilai karakter sekolah. SMA Karangturi dahulu berkembang dengan slogan semangatnya yaitu "Jembatan Meraih Prestasi" tetapi sekarang berubah menjadi "The Best You Can Be". Meski terjadi perubahan, kedua slogan tersebut sama-sama menitikberatkan pada prestasi atau capaian terbaik.

Visi SMA Karangturi adalah Karangturi is a School of Global Entrepreneurial Spirit (Karangturi adalah Sekolah Bertaraf Internasional dengan Semangat Kewirausahaan). Hal ini tidak bisa dipungkiri dipengaruhi oleh latar belakang siswa maupun pengelola sekolah yang merupakan etnis Tionghoa yang kebanyakan kaum pengusaha atau pedagang.

Misi SMA Karangturi yakni, membimbing peserta didik mendapatkan sikap yang baik, perilaku dan kepribadian ke arah badan yang sehat untuk pengembangan keterampilan dan kecerdasan yang sesuai bakat dan potensi mereka sebagai modal kesuksesesan di masa depan; membangun semangat wirausaha setiap peserta didik sehingga bisa mengambil manfaat dalam persaingan global; dan meningkatkan kemampuan mengajar dan staf administrasi melalui pelatihan dengan sikap profesional dan dedikasi tinggi dalam dunia pendidikan.

Falsafah pembelajaran SMA Karangturi adalah, mengenal gaya belajar yang berbeda diantara peserta didik yang biasanya dipengaruhi oleh kecerdasan yang menonjol dalam peserta didik; membangun nilai dan perilaku yang baik; dan membangun hubungan yang baik antara guru dan peserta didik dengan cara meluangkan waktu untuk bicara secara personal kepada peserta didik serta menghindarkan dari kekerasan dalam bentuk fisik maupun bahasa sarkastis saat pembelajaran.

Salah satu nilai karakter yang sangat menonjol dari sekolah Karangturi adalah Patriot. Patriot didasarkan pada nilai-nilai idealisme holistik yang digali dari Sekolah Karangturi dan nasionalisme. Pelaksanaan Patriot secara resmi dan menyeluruh untuk para guru, peserta didik, pengurus Yayasan dan karyawan dimulai tahun 2010, walaupun perintisannya sudah dikembangkan pada tahun-tahun sebelumnya. Patriot menjadi penting dalam membentuk kepribadian peserta didik karena tidak hanya cukup belajar mengolah pikir tetapi harus mampu olah hati, olah raga, dan olah rasa.

Keseluruhan nilai-nilai dalam Patriot dijabarkan dalam empat nilai penting yaitu Mind, Heart, Body, Soul. Empat nilai penting di dalamnya masih terdapat 10 nilai dasar (The Ten Fundamental Values) yaitu: Mind yang meliputi 3 nilai yakni Creativity, Analytical Thinking, dan Global Mindset; Heart yang meliputi 4 nilai yakni Respect, Responsibility, 
Caring, dan Trustworthiness; Body yang meliputi 2 nilai yakni Fitness, dan Health serta Soul yang meliputi 1 nilai yakni The existence of God. Pemahaman dan aplikasi Ten Fundamental Values yang baik diharapkan bisa memberdayakan Sumber Daya Manusia (SDM) Sekolah Karangturi termasuk para peserta didiknya untuk bisa berpikir kreatif dalam penciptaan ide dan karya yang secara otomatis memacu untuk menganalisis segala sesuatu berdasarkan pada wawasan global yang bersifat positif dan konstruktif tanpa meninggalkan jati dirinya. Penanaman nilainilai penghargaan atau penghormatan terhadap diri sendiri dan orang lain, rasa tanggung jawab, kepedulian terhadap lingkungan sekitar, yang secara sadar akan membentuk pribadi yang mempunyai integritas dan berjiwa patriotisme.

Secara akronim, program PATRIOT bermakna pula: Positive attitude, Ability to do the right thing, Trustworthy person, Respect and responsible person, Intellectual, Obey the rules, Trust in God. Jiwa Patriot ini mengajarkan perilaku positif, kemampuan untuk melakukan hal yang benar, menjadi orang yang dapat dipercaya, menjadi orang yang menghormati orang lain dan bertanggungjawab, menjadi orang yang pandai, mentaati aturan dan percaya pada Tuhan.

Sistem pembelajaran di SMA Karangturi menggunakan kurikulum pendidikan nasional dan ditambah kurikulum Cambridge. SMA Karangturi menerapkan sistem running class dengan 5 hari belajar yaitu hari Senin Jumat. Hari Sabtu digunakan untuk program clinical, program remidial, program pengayaan, pertemuan guru maupun yayasan. Running class merupakan strategi sekaligus program yang ditujukan positif untuk guru dan peserta didik. Bagi guru, running class dapat mengembangkan kreativitas dan inovasi dalam mengajar, menggunakan segala media pembelajaran serta perlengkapan yang mendukung proses belajar mengajar. Bagi peserta didik, running class berarti harus selalu berpindah ruang kelas mata pelajaran dan ini mengajarkan nilai kemandirian dalam belajar terutama mendatangi ruang kelas maupun menanyakan materi pembelajaran dan tugas kepada guru. Guru hanya berperan se- bagai fasilitator, membimbing kesulitan yang dialami peserta didik, dan mengarahkannya untuk bisa memahami serta mengaplikasikannya. Sistem running class meningkatkan interaksi dan hubungan sosial antara warga sekolah terutama antara peserta didik.

SMA Karangturi dalam usaha meningkatkan kualitas pendidikan yang berwawasan global berkomitmen mengembangkan kerjasama dengan sekolah yang ada di luar negeri diantaranya The Killmore International School (Melbourne, Australia), Serangoon Junior College (Singapura), Sekolah di China dan Hongkong. Kerjasama ini berupa pertukaran guru, pertukaran peserta didik, dan mengadopsi program-program sekolah yang bisa untuk pengembangan life skill peserta didik. Kerjasama yang berkelanjutan setiap tahun ini bertujuan untuk membuka wawasan pengembangan SMA Karangturi dan sebagai dorongan semangat berprestasi bagi peserta didik.

Sejarah pengembangan budaya berprestasi SMA Karangturi dapat dianalisis menggunakan fungsi adaptasi dalam teori fungsional struktural. Perkembangan budaya berprestasi SMA Karangturi yang bersifat dinamis menyesuaikan perkembangan masyarakat. Fungsi inilah yang dimaksudkan Parson dalam Johnson (130: 1990) sebagai penyesuaian dari sistem terhadap 'tuntutan kenyataan yang keras dan tidak dapat diubah' (inflexible) yang datang dari lingkungan. Penyesuaian lingkungan itu ada dua jenis yaitu sosial dan fisik. Penyesuaian lingkungan sosial SMA Karangturi dalam perkembangannya telah peka terhadap tuntutan orientasi masyarakat dalam pendidikan yaitu yang berawal dari menomor satukan akademik dan nilai ujian dan beralih pola pikir yang mementingkan keseimbangan dalam kecerdasan akademik dan non akademik.

Budaya sekolah di SMA Karangturi meliputi empat poin yaitu: keseimbangan antara pembinaan akademik dan nonakademik; penanaman karakter yang bisa dilakukan pada pelajaran muatan lokal maupun masuk setiap pelajaran, budaya mencintai almamater; dan pentingnya nilai kerokhanian atau spiritual.

Keseimbangan antara pembinaan aka- 
demik dan nonakademik sangat penting untuk memberikan wadah untuk berbagai kecerdasan peserta didik di SMA Karangturi sehingga menjadikannya prestasi yang membanggakan dan akhirnya bisa mendukung masa depan yang lebih baik. Peran sekolah inilah yang begitu penting dalam memotivasi dari awal kepada peserta didik untuk berani percaya diri mengaktualisasikan segala potensi diri. Keberhasilan di masa depan bukan cuma ditentukan oleh prestasi akademik. Peserta didik juga diarahkan untuk bisa mengembangkan secara seimbang kemampuan akademik dan non akademik.

Penanaman karakter sangat penting untuk menguatkan jiwa berbudaya dan nasionalisme. SMA Karangturi selain mengajarkan nilai-nilai karakter sekolah Karangturi dan semangat Patriot, juga mengajarkan bahasa dan budaya Jawa. Setiap hari kamis untuk seluruh warga sekolah memakai baju atasan batik dengan kebebasan motif coraknya dan setiap hari Jumat menggunakan seragam Patriot.

Pentingnya peserta didik mencintai almamater SMA Karangturi mengandung makna agar peserta didik harus menikmati dan menyenangi pengalaman dalam proses pembelajaran sehingga menumbuhkan kecintaan yang mendalam terhadap SMA Karangturi. Kecintaan terhadap almamater akan menjadikan SMA Karangturi selalu diperjuangkan bersama agar selalu berprestasi dan selalu memberikan masukan untuk kemajuan sekolah. Ikatan yang kuat antara para alumni dan SMA Karangturi akan menjadikan jaringan informasi dan kerjasama yang mempermudah hubungan dengan dunia luar terutama untuk pengembangan sekolah maupun peserta didik.

Menjunjung nilai kerokhanian atau spiritual juga merupakan budaya SMA Karangturi. Sekolah mentransfer nilai spiritual kepada peserta didik dengan memaknai kegiatan sosial yaitu selalu memberi dan peduli sebenarnya tidak kehilangan apa yang telah diberikan tetapi akan menjadikan berkah yang lebih banyak sehingga menjadi kebutuhan rohani yang harus selalu dilakukan.

Kepala Sekolah dan para guru sangat penting dalam pengembangan budaya se- kolah berprestasi. Kepala Sekolah menjadi pihak penting karena kepala sekolah adalah yang mengelola budaya sekolah dan yang memiliki kemampuan manajerial untuk pengelolaan kegiatan sekolah (Hidayat, 2005). Sementara itu guru merupakan pihak yang penting karena langsung berhadapan dengan peserta didik.

Tugas pengembangan budaya sekolah berprestasi terutama perencanaan dan evaluasi tidak bisa menjadi tanggung jawab pimpinan sekolah SMA Karangturi yang bersifat perintah atau Top-Bottom tetapi menjadi tugas bersama dan adakalanya bersifat Bottom-Up. Guru juga bisa mengusulkan maupun ikut mengevaluasi kegiatan maupun program sekolah yang berkaitan dengan budaya sekolah berprestasi di SMA Karangturi. Koordinasi dan kolaborasi bersama inilah menjadi faktor penting keserasian pandangan dan langkah untuk mencapai tujuan sekolah yang diharapkan.

Penanaman nilai dan etos budaya sekolah berprestasi SMA Karangturi dilakukan melalui proses pembelajaran di kelas, evaluasi belajar, proses pembelajaran di luar kelas, ekstrakurikuler, pemberian penghargaan prestasi, penanaman melalui simbolsimbol motivasi dan afirmatif, membangun kecintaan terhadap almamater, membangun keteladanan guru, membagun kerjasama dengan orang tua peserta didik, serta pemakaian seragam Patriot sebagai media penanaman budaya berprestasi.

Penanaman nilai dan etos budaya sekolah berprestasi SMA Karangturi memiliki faktor pendorong sekaligus penghambat. Salah satu faktor pendorong adalah sumber belajar yang berupa fasilitas yang tersedia di SMA Karangturi yang bisa membantu proses pembelajaran di SMA Karangturi yang lebih mengutamakan keaktifan dan pengalaman peserta didik. Faktor pendorong lain adalah pembelajaran di SMA Karangturi yang selalu mendukung untuk peserta didik untuk bisa mengembangkan materi pelajaran lebih luas lagi, menemukan manfaat dan bisa berprestasi di dalam dan di luar sekolah. Pembelajaran yang menekankan proses belajar dan evaluasi belajar yang disiplin, ketat dan disertai budaya peserta didik maupun 
orangtuanya untuk meraih prestasi memacu atmosfir persaingan yang sangat kuat dan terlihat di lingkungan sekolah. Atmosfir persaingan yang kuat di dalam kelas memberikan efek positif terhadap semangat belajar setiap peserta didik.

Faktor pendorong yang lain adalah ketersediaan teknologi informasi dan kemampuan peserta didik SMA Karangturi untuk dengan leluasa memanfaatkannya. Peserta didik di SMA Karangturi yang mayoritas berasal dari keluarga ekonomi menengah ke atas, banyak yang memiliki perangkat komputer ataupun telepon genggam yang bisa terhubung dengan internet dan banyak juga yang mengikuti bimbingan belajar di luar sekolah. Hal ini sangat membantu dalam proses belajar siswa sehingga dapat meningkatkan hasil belajar.

Faktor berikutnya yang mendorong penanaman budaya berprestasi adalah guru di SMA Karangturi yang mampu menganalisis kebutuhan peserta didik dari segi materi pelajaran, menggunakan metode pembelajaran yang lebih menyenangkan, memvisualisasikan dan mendekatkan pembelajaran dengan dunia nyata, mengembangkan metode pembelajaran yang bisa diterima dengan baik dan selalu memberikan motivasi.

Faktor berikutnya adalah SMA karangturi memiliki program olimpiade dan persiapan kompetisi yang diadakan ketika ada kompetisi yang akan diikuti oleh sekolah. Ekstrakurikuler di SMA karangturi juga tidak hanya sebatas pengembangan bakat maupun hobi tetapi juga untuk mempersiapkan keikutsertaan dalam lomba maupun kompetisi sehingga tujuannya adalah prestasi.

Hubungan yang baik antara orangtua peserta didik, sekolah dan yayasan Karangturi dalam bentuk perhatian terhadap prestasi SMA Karangturi juga menjadi faktor pendorong penanaman budaya berprestasi. Orangtua peserta didik selalu memantau prestasi anaknya, ketersediaan fasilitas belajar, dan proses pembelajaran yang berlangsung di sekolah, dan memberikan masukan untuk kemajuan.

Peran penting Yayasan Karangtuti dalam penanaman nilai-nilai berprestasi di
SMA Karangturi juga menjadi faktor pendorong Fungsi integration dalam pengembangan budaya sekolah berprestasi di SMA Karangturi adalah dengan mengatur hubungan komponen-komponen pendidikan yang ada di dalamnya agar dapat berfungsi secara maksimal. Hubungan komunikasi yang baik diantara YPN Karangturi, sekolah, peserta didik, keluarga, dan alumni akan menciptakan pemahaman yang sama mengenai norma budaya sekolah sehingga dengan penuh kesadaran, kepercayaan dan kerelaan untuk mewujudkannya.

Selain faktor pendorong yang telah disampaikan, terdapat pula beberapa faktor yang menghambat penanaman budaya berprestasi di SMA Karangturi. Salah satunya adalah keterbatasan dalam memfasilitasi bakat nonakademik peserta didik di bidang olahraga tertentu, karena sempitnya lahan sekolah Karangturi untuk kegiatan olahraga. Selama ini Karangturi memang terkenal sangat berprestasi dalam olahraga basket, namun untuk olahraga lainnya nampaknya sekolah ini kesulitan dalam pengembangan karena keterbatasan lahan.

Hambatan lain yang dialami adalah sering terjadinya miskomunikasi orangtua peserta didik terutama kelas $\mathrm{X}$, yang tampak pada seringnya mereka memprotes sekolah mengenai banyaknya penugasan yang diberikan guru kepada peserta didik. Namun sekolah menganggap penugasan tersebut sangat penting untuk tetap dilakukan karena memberi keuntungan pada siswa saat menjalani proses pembelajaran maupun selepas SMA.

Faktor penghambat lain adalah faktor keluarga. Kehidupan siswa SMA Karangturi yang sebagian besar serba ada dan penuh kemudahan menimbulkan perilaku kurang disiplin dan kurang menghargai kerja keras. Perilaku inilah yang diupayakan untuk dirubah oleh sekolah dari awal masuk yaitu Masa Orientasi Siswa (MOS) dan dalam proses pembelajaran. Kedisiplinan merupakan salah satu pondasi yang penting dalam pengembangan budaya sekolah berprestasi. Faktor surutnya tingat ekonomi keluarga juga bisa menjadi hambatan bagi peserta didik. Pada beberapa kasus, faktor ini menyebabkan nilai akademik peserta didik bersang- 
kutan menurun drastis.

Faktor penghambat berikutnya adalah kecenderungan peserta didik lebih aktif dalam bidang tertentu serta kurang tertarik pada bidang lain. dan inisiatif bertanya di dalam kelas yang kurang.

Pergaulan peserta didik juga menjadi salah satu faktor penghambat penanaman budaya berprestasi. Peserta didik cederung mengelompok sesama tionghoa, atau berdasar asal SMP yang peserta didiknya juga sebagian besar Tionghoa. Peserta didik diluar kelompok tersebut atau tidak Tionghoa membutuhkan waktu lebih lama untuk bisa pendekatan untuk bergaul dengan sesama teman dan beradaptasi mengenai budaya sekolah Karangturi. Faktor penghambat berikutnya adalah keterbatasan fisik sarana dan prasarana terutama lahan hijau menjadi kendala yang berarti untuk pembelajaran lingkungan.

Bentuk implikasi dari pengembangan budaya sekolah berprestasi di SMA Karangturi mencakup input, proses dan output. Secara input, SMA Karangturi mampu secara mandiri menseleksi calon peserta didik lewat Penerimaan Siswa Baru (PSB). yang dilaksanakan dengan teratur, sistematis, teratur dan selektif. Sekolah ini tidak pernah khawatir kekurangan atau mencari peserta didik. Program sekolah dalam pengelolaan input peserta didik diantaranya OSKAR (orientasi Karangturi), Smart Camp, pembimbingan gaya belajar, dan pengarahan keikutsertaan ekstrakurikuler mampu membentuk situasi pembelajaran awal yang memudahkan peserta didik untuk cepat masuk dalam budaya sekolah berprestasi. Pemberdayaan peserta didik sejak awal masuk tahun pertama merupakan bentuk prestasi dalam input yang nantinya akan menuju keberlajutan pada proses dan output.

Bentuk proses dalam prestasi adalah kinerja sekolah yang memuat program sekolah, inovasi yang dikembangkan, kerjasama instansi maupun etos dalam upaya mendukung budaya berprestasi. Visi misi SMA Karangturi yang dilengkapi dengan falsafah pembelajaran dan karakter Patriot telah memberikan dasar yang kuat sekaligus arahan yang jelas untuk program-progam se- kolah yang akan dikembangkan. Nilai-nilai semangat wirausaha berwawasan global telah dikembangkan dengan nilai-nilai dan etos kerja keras, disiplin, persaingan yang sehat, kepemimpinan, dan kepedulian. Inovasi pembelajaran yang dikembangkan di dalam kelas, luar kelas (clinical dan tim olimpiade) maupun ekstrakurikuler menjadi strategi untuk selalu mengikuti perkembangan pendidikan. Kerjasama SMA Karangturi dengan beberapa sister school yang ada di luar negeri menjadi bukti pengembangan sekolah ke arah standar internasional. Profesionalisme yang tinggi dan hubungan antara guru, kepala sekolah dan yayasan yang dekat diwujudkan dalam rapat bersama dalam hal perkembangan inovasi pembelajaran, evaluasi prestasi sekolah, maupun bentuk keakraban (sharing, rekreasi bersama atau outbond).

Dalam hal output, prestasi SMA Karangturi berwujud dalam dua bentuk yaitu prestasi akademik dan prestasi non akademik. Prestasi SMA Karangturi menunjukkan keseimbangan antara prestasi akademik dan prestasi non akademik. Prestasi yang diraih peserta didik SMA Karangturi ini merupakan hasil budaya sekolah berprestasi yang ditanamkan mulai pertama kali masuk dan selama proses pembelajaran. Prestasi peserta didik SMA Karangturi juga didukung oleh guru-guru dan pembina ekstrakurikuler yang banyak berkualitas dan ahli dalam bidangnya serta keaktifan membina peserta didik untuk mengikuti kompetisi.

Output dalam prestasi akademik terlihat dari banyaknya lulusan SMA Karangturi banyak yang diterima di perguruan tinggi dalam negeri dan luar negeri. Sebagian alumni ada yang memilih perguruan tinggi luar negeri dengan biaya sendiri maupun beasiswa. Berdasarkan data alumni SMA Karangturi lulusan Tahun 2011, Persentasi peserta didik yang melanjutkan sebesar $93 \%$ dan sisanya $7 \%$ kemungkinan tidak menginformasikan ke pihak sekolah atau bekerja.

Alumni SMA Karangturi tidak hanya memiliki kecerdasan pengetahuan tetapi juga cerdas secara emosional spiritual, berjiwa wirausaha, pekerja keras, tahan terhadap tekanan dan mempunyai banyak hubungan usaha. Budaya berprestasi ini melekat sam- 
pai dunia kerja dan di kehidupan masyarakat menjadi pengusaha sekaligus pemimpin yang berkarakter dan berjiwa sosial.

Pengembangan budaya sekolah berprestasi memang tidak hanya dilihat dalam prosesnya, kelulusan maupun langsung terlihat hasilnya tetapi juga prestasi yang paling penting adalah karakter dalam jangka waktu yang lama. Output prestasi yang dianggap berharga adalah kesan yang baik oleh para alumni sehingga merasakan manfaatnya di masa depan.

\section{SIMPULAN}

Bentuk budaya sekolah berprestasi di SMA Karangturi terwujud dalam slogan "The Best You Can Be", serta visi "Karangturi is a School of Global Entrepreneurial Spirit" dan dikembangkan lagi dalam tiga misi, falsafah pembelajaran SMA Karangturi dan nilai karakter Patriot. Etos yang dominan yang mengiringi berjalannya nilai-nilai budaya sekolah berprestasi adalah kerja keras, persaingan belajar dan kecintaan terhadap almamater. Pengembangan budaya sekolah berprestasi di SMA Karangturi mencakup empat poin yaitu: keseimbangan antara pembinaan akademik dan nonakademik, penanaman karakter yang bisa dilakukan pada pelajaran muatan lokal maupun masuk setiap pelajaran, budaya mencintai almamater dan pentingnya nilai kerokhanian atau spiritual.

Penanaman nilai dan etos berprestasi pada peserta didik di SMA Karangturi dimulai melalui proses orientasi sekolah, proses pembelajaran di kelas (pembimbingan gaya belajar, kewirausahaan dan kepemimpinan), evaluasi belajar, proses pembelajaran di luar kelas (clinical, pagelaran sekolah, dan tour kampus), ekstrakurikuler, penghargaan prestasi (beasiswa, point reward, Bintang Pelajar dan Acknowledgmen of Personal Appraisal), simbol-simbol motivasi dan afirmatif, kecintaan terhadap almamater, membangun keteladanan guru, membangun kerjasama dengan orangtua peserta didik dan seragam patriot sebagai media penanaman budaya berprestasi. Pembelajaran di SMA Karangturi lebih menekankan pada pentingnya pengalaman dalam proses belajar. Program ino- vasi sekolah, proses pembelajaran, motivasi, penghargaan, kedekatan hubungan diantara komponen-komponen warga sekolah dan program Patriot memberikan dorongan dan kontribusi yang positif terhadap prestasi SMA Karangturi.

Bentuk hasil dari penanaman nilai dan etos berprestasi di SMA Karangturi mencakup prestasi dalam input, proses dan output. Prestasi dalam input yaitu progam Penerimaan Siswa Baru (PSB) dengan berbagai jalur yang tidak pernah sepi peminat, pemberdayaan sejak masa orientasi sekolah, pembimbingan gaya belajar, pengarahan keikutsertaan ekstrakurikuler, dan pencarian bibit-bibit peserta didik yang berpotensi dan dibimbing dalam tim olimpiade ternyata mampu membentuk situasi pembelajaran awal yang memudahkan peserta didik untuk cepat masuk dalam budaya sekolah berprestasi. Prestasi dalam proses yaitu kinerja dalam proses pembelajaran lebih menekankan pada semangat kerja keras, persaingan belajar yang sehat, kepemimpinan dan kepedulian. Prestasi dalam output bisa terlihat dari banyaknya perolehan juara dalam kompetisi akademik maupun nonakademik di tingkat internasional, nasional, provinsi dan kota, serta banyaknya alumni yang melanjutkan di perguruan tinggi di dalam negeri dan beberapa mendapat beasiswa di luar negeri.

\section{DAFTAR PUSTAKA}

Amir, Y.H. 2005. Kepemimpinan Kepala Sekolah yang Berorientasi Penguatan Budaya Organisasi dan Perbaikan Mutu Pendidikan di Sekolah Swasta Berciri Khas Islam: Model Konseptual Berdasarkan Kasus SMA Al-Irsyad Tegal. Mimbar Pendidikan No. 2/XXIV/2005

Aritonang, K.T. 2008. Minat dan Motivasi dalam Meningkatkan Hasil Belajar Siswa. Jurnal Pendidikan Penabur. 7(10)

Bukhori, I. dan Anita, N. 2009. Pengaruh Kultur Sekolah Terhadap Motivasi Belajar Siswa Melalui Kinerja Guru. Jurnal Penelitian Kependidikan. 19(2): $60-80$

Garliah, L. dan Nasution, F.K. 2005. Peran Pola Asuh Orang Tua dalam Motivasi Berprestasi. Jurnal Psikologia. 1

Isjoni. 2006. Pendidikan sebagai Investasi Masa Depan. Jakarta: Yayasan Obor Indonesia

Isriani, H. 2011. Pembelajaran Sosiologi Yang Menggugah Minat Siswa. Jurnal Komunitas. 3(1): 108-125 
Agus Yuliono / Komunitas 3 (2) (2011) : 169-179

Johnson, D.P. 1990. Teori Sosiologi Klasik dan Modern. Jakarta: Gramedia

Koentjaraningrat. 2000. Pengantar Ilmu Antropologi. Jakarta: PT. Rineka Cipta

Liliweri, A. 2003. Makna Budaya dalam Komunikasi antar Budaya. Yogyakarta: LKiS

Masinambow, E.K.M. (Ed.). 1997. Koentjaraningrat dan Antropologi di Indonesia. Jakarta: Yayasan Obor Indonesia

Moleong, L. 2002. Metodologi Penelitian Kualitatif. Bandung: Remaja Rosda Karya
Olim, A., dkk. 2007. 'Teori Antropologi Pendidikan'. Dalam Jurnal Ilmu Pendidikan Teoritis. Hal. 253283

Prastiti, S.D. dan Pujiningsih, S. 2009. Pengaruh Faktor Preferensi Gaya Belajar terhadap Prestasi Belajar Mahasiswa Akuntansi. Jurnal Ekonomi Bisnis. 14(3) :20-35

Sugiyono. 2008. Metode Penelitian Pendidikan: Pendekatan Kuantitatif, Kualitatif, dan $R \& D$. Bandung; Alfabeta. 